\title{
SUPERVISI PENDIDIKAN PERSPEKTIF HADIS NABI DAN PENGEMBANGANNYA DALAM MENINGKATKAN KUALITAS PROFESIONALISME GURU
}

\author{
Nur Laily Fauziyah
}

Stit Al Marhalah Al Ulya Bekasi

Email: lailyfauziyah@gmail.com

\begin{abstract}
Abstrak
Dalam Al-Qur'an maupun dalam Hadist-hadist banyak kita jumpai istilahistilah yang berkaitan dengan kepemimpinan di antaranya : Amir, Khalifah, Imamah dsb. ini berarti Islam telah lebih dahulu mengetahui dan menetapkan mengani asas-asas kepemimpinan jauh sebelum para ahli Barat membahasnya. Namun, berbagai teori yang digambarkan para ahli mengenai kepemimpinan tak jarang membuat orang tidak memahami akan arti sebenarnya tentang kepemimpinan dalam Islam. Sehingga hampir kebanyakan pemimpin saat ini, telah lari dari arti kepemimpinan dalam ajaran Islam.

Supervisi merupakan suatu teknis pelayanan profesional dengan tujuan utama mempelajari dan memperbaiki bersama-sama dalam membimbing dan mempengaruhi pertumbuhan anak. Menurut Kimbal Wiles menegaskan bahwa supervisi berusaha untuk memperbaiki situasi-situasi belajar mengajar, menumbuhkan kreativitas guru, memberi dukungan dan mengikutsertakan guru dalam kegiatan sekolah, sehingga menumbuhkan rasa memiliki bagi guru. Adapun personel yang menjalankan kegiatan supervisi disebut supervisor.
\end{abstract}

Kata Kunci: supervisi, profesional guru 


\section{Pendahuluan}

Dalam Al-Qur'an maupun dalam Hadist-hadist banyak kita jumpai istilahistilah yang berkaitan dengan kepemimpinan di antaranya : Amir, Khalifah, Imamah dsb. ini berarti Islam telah lebih dahulu mengetahui dan menetapkan mengani asas-asas kepemimpinan jauh sebelum para ahli Barat membahasnya. Namun, berbagai teori yang digambarkan para ahli mengenai kepemimpinan tak jarang membuat orang tidak memahami akan arti sebenarnya tentang kepemimpinan dalam Islam. Sehingga hampir kebanyakan pemimpin saat ini, telah lari dari arti kepemimpinan dalam ajaran Islam.

Seringkali orang memahami kepemimpinan dalam arti sempit sekali. Sehingga mereka mengetahui kepemimpinan adalah para pemimpin negara, wilayah, perusahaan dsb. Ketidak sadaran inilah yang mengakibatkan orang tidak mau mengembangkan ilmu kepemimpinannya.

\section{Pembahasan}

1. Pengertian Supervisi Pendidikan

Secara etimologis istilah "Supervisi" yang dalam bahasa Inggris "supervision" sering diartikan dengan pengawasan/kepengawasan. Secara marfologis, "Supervisi" terdiri dari "super" berarti atas, atau lebih dan "visi" yang berarti lihat/penglihatan, pandang, tilik atau awasi. ${ }^{1}$ Orang yang mengerjakan supervisi disebut supervisor. Menurut konsep kuno supervisi dilaksanakan dalam bentuk "inspeksi" atau mencari kesalahan. Sedangkan pandangan modern supervisi adalah usaha untuk memperbaiki situasi belajar mengajar, yaitu sebagai bantuan bagi guru dalam mengajar untuk membantu siswa agar lebih baik dalam belajar. Menurut Burton, secara umum supervisi berarti upaya bantuan yang diberikan kepada guru dalam melaksanakan tugas profesionalnya, agar guru mampu membantu para siswanya dalam belajar untuk menjadi lebih baik dari sebelumnya.

Supervisi merupakan suatu teknis pelayanan profesional dengan tujuan utama mempelajari dan memperbaiki bersama-sama dalam membimbing dan mempengaruhi pertumbuhan anak. Menurut Kimbal Wiles menegaskan bahwa supervisi berusaha untuk memperbaiki situasi-situasi belajar mengajar, menumbuhkan kreativitas guru, memberi dukungan dan mengikutsertakan guru dalam kegiatan sekolah, sehingga menumbuhkan rasa memiliki bagi guru. Adapun personel yang menjalankan kegiatan supervisi disebut supervisor.

Menurut Good Carter, supervise adalah segala usaha dari petugas-petugas sekolah dalam memimpin guru-guru dan petugas pendidikan lainnya dalam memperbaiki pengajaran, termasuk memperkembangkan pertumbuhan guruguru, menyelesaikan dan merevisi tujuan pendidikan, bahan-bahan pengajaran dan metode mengajar dan penilaian pengajaran.

Sedangkan menurut Boardman, supervisi adalah suatu usaha menstimulir, mengkoordinir dan membimbing secara kontinu pertumbuhan guru-guru sekolah, baik secara individual maupun secara kolektif, agar lebih mengerti, dan lebih efektif dalam mewujudkan seluruh fungsi pengajaran, sehingga dengan demikian mereka mampu dan lebih cakap berpartisipasi dalam masyarakat demokrasi modern. ${ }^{2}$

${ }^{1}$ Prof. Dr. Engkoswara, M.Ed. dan Dr.Hj.Aan Komariah, M.Pd., Administrasi Pendidikan, (Bandung: Alfabeta, 2015), hlm. 228

${ }^{2}$ Drs.H.M. Daryanto, Administrasi Pendidikan, (Jakarta: Rineka Cipta, 2014), hlm. 170 
Supervisi disamakan dengan pekerjaan mengawasi, supervisi lebih banyak mengawasi daripada berbagai ide pengalaman. Guru cenderung menjadi resah dan takut apabila mereka diawasi, sehingga kebanyakan guru tidak suka disupevisi walaupun hal itu merupakan bagian proses pendidikan.

Jadi supervisi mempunyai pengertian yang luas, dimana segala bantuan dari pimpinan sekolah, yang tertuju kepada perkembangan kepemimpinan guruguru dan personal sekolah lainnya di dalam mencapai tujuan pendidikan. Dengan kata lain dapat disimpulkan dari beberapa pendapat bahwa supervisi ialah suatu aktivitas pembinaan yang direncanakan untuk membantu para guru dan pegawai sekolah lainnya dalam melakukan pekerjaan mereka secara efektif. Peningkatan kinerja guru ditentukan oleh tingkat keberhasilan peran kepala sekolah, dalam hal ini kepala sekolah sebagai administrator dan supervisor. Sementara itu pembinaan yang dilakukan oleh kepala sekolah diantaranya adalah membenahi kekurangan dan kelemahan dalam melaksanakan tanggung jawab yang diembannya. Sedangkan strategi yang dapat diterapkan oleh kepala sekolah diantaranya adalah menerapkan arah tindakan dan cara yang sifatnya mendasar melalui perencanaan, pelaksanaan dan evaluasi, itu semua diharapkan untuk meningkatkan kualitas dalam melaksanakan tugasnya sesuai dengan tujuan yang ditetapkan. Kepala sekolah sebagai pimpinan puncak lembaga pendidikan berkewajiban memberikan arahan, bimbingan, motivasi, pembinaan, peningkatan dan pengembangan para guru dan staf tata usaha, serta menumbuhkan kreatifitas dan produktivitas yang tinggi untuk hasil yang maksimal.

\section{Tujuan Supervisi Pendidikan}

Dalam melakukan suatu pekerjaan orang yang terlibat dalam pekerjaan itu harus mengetahui dengan jelas apakah tujuan pekerjaan itu, yaitu apa yang hendak dicapai. Di bidang pendidikan dan pengajaran seorang supervisor pendidikan harus mempunyai pengetahuan yang cukup jelas tentang apakah tujuan supervisi itu.

Tujuan umum supervisi pendidikan adalah memperbaiki situasi belajar mengajar, baik belajar para siswa, maupun situasi mengajar guru. Wiles dan W.H. Burton sebagaimana dikutip oleh Burhanuddin mengungkapkan bahwa tujuan supervisi pendidikan adalah membantu mengembangkan situasi belajar mengajar ke arah yang lebih baik. Tujuan supervise pendidikan tidak lain adalah untuk meningkatkan pertumbuhan siswa dan dari sini sekaligus menyiapkan bagi perkembangan masyarakat.

Amatembun merumuskan tujuan supervisi pendidikan (dalam hubungannya dengan tujuan pendidikan nasional) yaitu membina orang-orang yang disupervisi menjadi manusia-manusia pembangunan yang dewasa yang berpancasila.

Yushak Burhanuddin mengemukakan bahwa tujuan supervisi pendidikan adalah dalam rangka mengembangkan situasi belajar mengajar yang lebih baik melalui pembinaan dan peningkatan profesi mengajar, secara rinci sebagai berikut:

a. Meningkatkan efektifitas dan efisiensi dalam belajar

b. Mengendalikan penyelenggaraan pendidikan bidang teknis edukatif di sekolah sesuai dengan ketentuan-ketentuan dan kebijakan.

c. Menjamin agar kegiatan sekolah berlangsung sesuai dengan ketentuan yang berlaku, sehingga berjalan lancar dan memperoleh hasil optimal. 
d. Menilai keberhasilan sekolah dalam pelaksanaan tugasnya

e. Memberikan bimbingan langsung untuk memperbaiki kesalahan, kekurangan, dan kekhilafan serta membantu memecahkan masalah yang dihadapi sekolah, sehingga dapat dicegah kesalahan yang lebih jauh.

Secara nasional tujuan konkrit dari supervisi pendidikan adalah:

a. Membantu guru melihat dengan jelas tujuan-tujuan pendidikan

b. Membantu guru dalam membimbing pengalaman belajar murid.

c. Membantu guru dalam menggunakan alat pelajaran modern.

d. Membantu guru dalam menilai kemajuan murid-murid dan hasil pekerjaan guru itu sendiri.

e. Membantu guru dalam menggunakan sumber-sumber pengalaman belajar.

f. Membantu guru dalam memenuhi kebutuhan belajar murid.

g. Membantu guru dalam membina reaksi mental atau moral kerja guru dalam rangka pertumbuhan pribadi dan jabatan mereka.

h. Membantu guru baru di sekolah sehingga mereka merasa gembira dengan tugas yang diperolehnya.

i. Membantu guru agar lebih mudah mengadakan penyesuaian terhadap masyarakat dan cara-cara menggunakan sumber-sumber yang berasal dari masyarakat.

j. Membantu guru-guru agar waktu dan tenaganya tercurahkan sepenuhnya dalam pembinaan sekolah.

\section{Fungsi Supervisi Pendidikan}

Menurut W.H. Burton dan Leo. J. Bruckner sebagaimana dikutip oleh Piet A. Sahertian menjelaskan bahwa fungsi utama supervisi adalah menilai dan memperbaiki faktor-faktor yang mempengaruhi hal belajar. Oteng Sutisna mengemukakan beberapa fungsi supervisi :

a. Sebagai penggerak perubahan

b. Sebagai program pelayanan untuk memajukan pengajaran

c. Sebagai keterampilan dalam hubungan manusia

d. Sebagai kepemimpinan kooperatif. ${ }^{3}$

Adapun menurut Swearingen, fungsi supervisi pendidikan antara lain:

a. Mengkoordinir semua usaha sekolah

b. Memperlengkapi kepemimpinan sekolah

c. Memperluas pengalaman guru-guru

d. Menstimulir usaha-usaha yang kreatif

e. Memberikan fasilitas dan penilaian yang terus menerus

f. Menganalisis situasi belajar dan mengajar

g. Memberikan skill kepada setiap anggota staf. ${ }^{4}$

4. Supervisi Pendidikan Perspektif Hadis Nabi

Berikut ini hadits mengenai supervisi pendidikan:

a. Akuntabilitas (Tanggung Jawab Terhadap Amanah Sebagai Pemimpin)

\footnotetext{
${ }^{3}$ Oteng Sutisna, Administrasi dan Supervisi Pendidikan Dasar dan Teoritis Untuk Praktek Profesional, (Bandung : Angkasa 1989), Edisi Ke-5.

${ }^{4}$ H.M.Daryanto, Administrasi Pendidikan, (Jakarta: Rineka Cipta, 2014), hlm. 179
} 
Dalam supervisi pendidikan dikenal dengan prinsip "Akuntabilitas" yakni segala sesuatu yang ditugaskan pada seorang pendidik atau supervisor termasuk amanah dari Allah SWT., maupun dari orangtua peserta didik yang suatu saat akan dimintai pertanggung jawaban dalam pelaksanaan tugasnya. Hal tersebut sesuai dengan hadits Nabi:

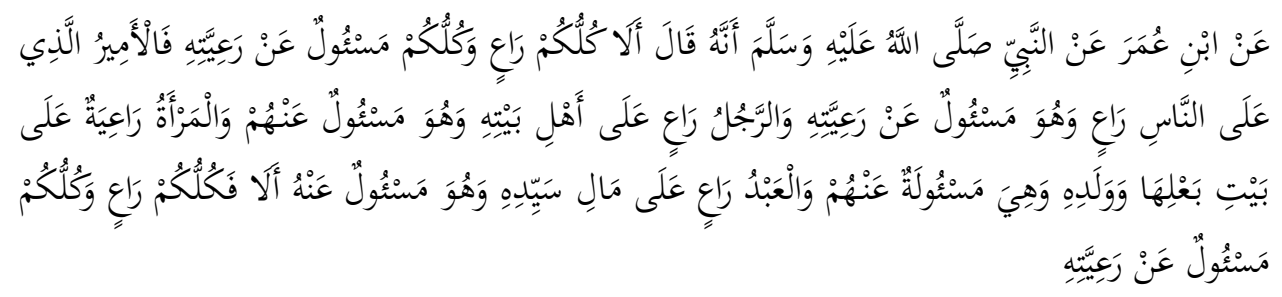

Artinya: Setiap kamu adalah pemimpin dan setiap kamu akan dimintai pertanggung jawaban terhadap apa yang kamu pimpin. Seorang raja adalah pemimpin bagi rakyatnya, dan dia akan dimintai pertanggungjawaban terhadap apa yang dipimpinnya. Seorang suami adalah pemimpin bagi anggota keluarganya dan dia akan dimintai pertanggung jawaban terhadap mereka. Seorang istri adalah pemimpin bagi rumah tangga, suami dan anak-anaknya, dan dia akan dimintai pertanggung jawaban terhadapa apa yang dipimpinnya. Seorang hamba adalah pemimpin bagi harta majikannya, dan dia juga akan dimintai pertanggung jawaban terhadap apa yang dipimpinnya. Dan ingat setiap kaти adalah pemimpin dan akan dimintai pertanggung jawaban terhadap kepemimpinannya.

b. Edukatif ; Berbuat Yang Terbaik dalam Tugas Kependidikan

Salah satu hadis nabi yang berkaitan dengan supervisi pendidikan yaitu:

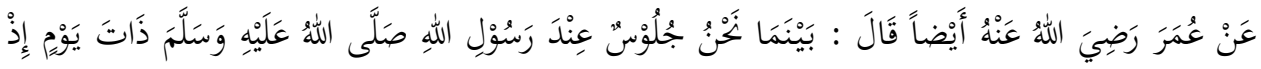

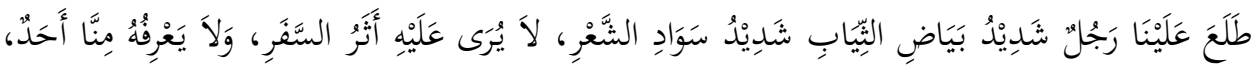

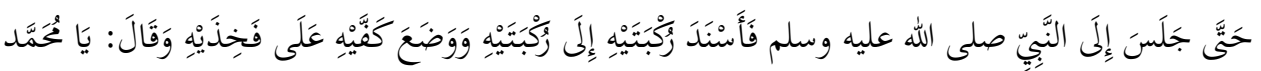

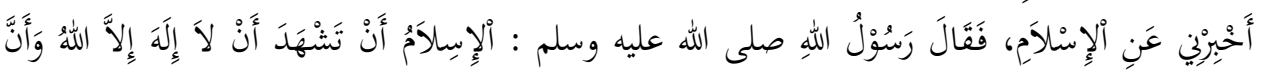

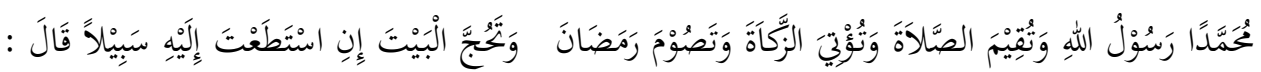

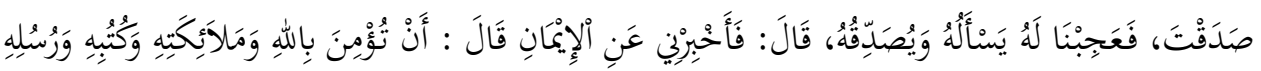

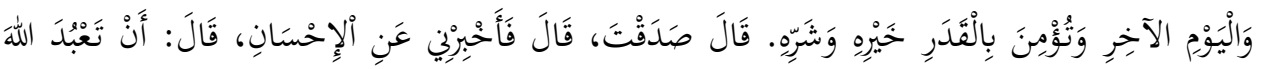

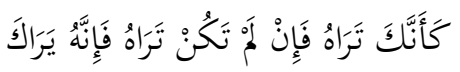

Artinya:"Dari Umar radhiallahuanhu juga dia berkata : Ketika kami duduk-duduk disisi Rasulullah Shallallahu'alaihi wasallam suatu hari tibatiba datanglah seorang laki-laki yang mengenakan baju yang sangat putih dan berambut sangat hitam, tidak tampak padanya bekas-bekas perjalanan jauh dan tidak ada seorangpun diantara kami yang mengenalnya. Hingga kemudian dia duduk dihadapan Nabi lalu menempelkan kedua lututnya kepada kepada lututnya (Rasulullah Shallallahu'alaihi wasallam) seraya 
berkata: “Ya Muhammad, beritahukan aku tentang Islam ?”, maka bersabdalah Rasulullah Shallallahu'alaihi wasallam : "Islam adalah engkau bersaksi bahwa tidak ada Ilah (Tuhan yang disembah) selain Allah, dan bahwa Nabi Muhammad adalah utusan Allah, engkau mendirikan shalat, menunaikan zakat, puasa Ramadhan dan pergi haji jika mampu ", kemudian dia berkata: " anda benar ". Kami semua heran, dia yang bertanya dia pula yang membenarkan. Kemudian dia bertanya lagi: “ Beritahukan aku tentang Iman ". Lalu beliau bersabda: “Engkau beriman kepada Allah, malaikat-malaikat-Nya, kitab-kitab-Nya, rasul-rasul-Nya dan hari akhir dan engkau beriman kepada takdir yang baik maupun yang buruk ", kemudian dia berkata: " anda benar". Kemudian dia berkata lagi: "Beritahukan aku tentang ihsan ". Lalu beliau bersabda: "Ihsan adalah engkau beribadah kepada Allah seakan-akan engkau melihatnya, jika engkau tidak melihatnya maka Dia melihat engkau” (H.R Muslim).

Dalam hadits tersebut, Islam dibangun dengan tiga aspek, yaitu Iman, Islam dan Ihsan. Iman menyangkut aspek theologi, sedangkan Islam menyangkut aspek syariat atau beribadah. Yang terakhir adalah Ihsan yang menyangkut aspek akhlak. Dalam penjelasan hadits tersebut, definisi Ihsan adalah, Beritahukan aku tentang ihsan ". Lalu beliau (Muhammad) bersabda: " Ihsan adalah engkau beribadah kepada Allah seakan-akan engkau melihatnya, jika engkau tidak melihatnya maka Dia melihat engkau”. Setiap langkah maupun nafas kita, akan selalu diawasi oleh Allah. Ketika Allah mengawasi hambanya tidak diragukan lagi keadilannya. Berbeda dengan pengawas manusia, mungkin ada segelintir pengawas yang tidak memenuhi prosedur. Hal inilah yang membuat seorang supervisor maupun sebagai pendidik termotivasi untuk selalu berbuat yang terbaik dalam melaksanakan tugas-tugasnya karena bahwasanya semua diawasi bukan hanya di dunia saja, akan tetapi juga di akhirat. Oleh karena itu kepala sekolah sebagai supervisor harus selalu memberikan motivasi, pengarahan kepada guru, dan guru sebagai pendidik harus memberikan pengajaran serta keteladanan yang baik terhadap peserta didiknya.

c. Korektif dan Introspeksi Diri (Control/Evaluasi Diri)

Beberapa hadits Rasulullah SAW. menganjurkan perlunya melaksanakan pengawasan atau evaluasi dalam setiap pekerjaan. Ajaran Islam sangat memperhatikan adanya bentuk pengawasan terhadap diri terlebih dahulu sebelum melakukan pengawasan terhadap orang lain. Hal ini antara lain berdasarkan hadits Rasulullah SAW., sebagai berikut:

$$
\begin{aligned}
& \text { حدثنا سفيان بن وكيع حدثنا عيسى بن يونس عن أبي بكر بن أبي مريم وحدثنا عبد الله بن عبد الرحمن }
\end{aligned}
$$

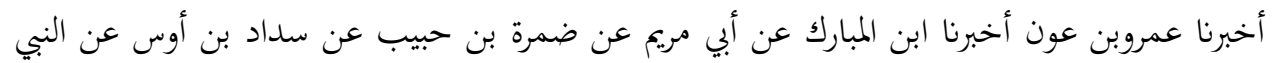

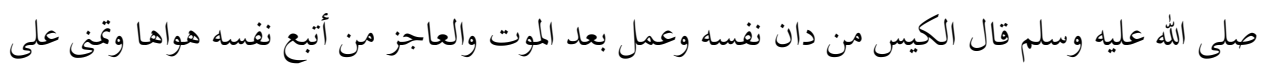

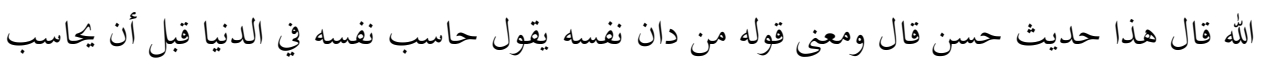

$$
\begin{aligned}
& \text { يوم القيامة ويروى عن عمر بن الخطاب قال حاسبوا أنفسكم قبل أن تحاسبوا وتزينوا للعرض الأكبر وإنما }
\end{aligned}
$$




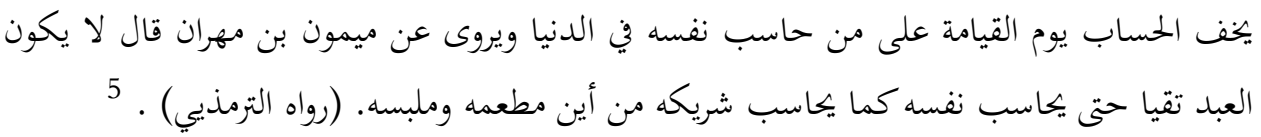

"Menceritakan pada kami Sufyan bin Waki', menceritakan pada kami Isa bin Yunus, dari Abi Bakar bin Abi Maryam (al hadits...), Menceritakan pada kami Abdullah bin Abdurrahman, memberitahukan pada kami Amr bin 'Aun, menceritakan pada kami Ibnul Mubarok, dari Abi Bakar bin Abi Maryam dari Dlamrah bin Habib dari Syaddad bin Aus dari Nabi SAW. bersabda: "Orang yang cerdas itu adalah orang yang mengalahkan hawa nafsunya dan melakukan perbuatan untuk (kehidupan setelah mati), sedangkan orang yang lemah adalah orang yang mengikuti hawa nafsunya dan berangan-angan kepada Allah (berharap akan takdir-Nya). Sufyan berkata "ini hadits hasan", berkata lagi Maksud "Man daana nafsahu” adalah mengevaluasi dirinya di dunia sebelum dihisab nanti di hari kiamat. Dan diriwayatkan dari Umar bin Khattab berkata: "Evaluasilah diri kalian sebelum dihisab di akhirat dan berhiaslah untuk kehormatan yang besar dan bahwasanya hisab pada hari kiamat diringankan bagi orang yang mengevaluasi dirinya di dunia. Diriwayatkan juga dari Maimun bin Mihran berkata: "Tidak dikatakan hamba yang bertakwa, sehingga ia mengevaluasi dirinya sebagaimana menginterogasi temannya dari mana ia mendapat makanan dan pakaian. (HR. Turmudzi).

Dalam suatu proses pembelajaran sampai pada kependidikan, tentunya terjadi kesalahan, penyimpangan bahkan kebocoran yang pastinya dicari penyebabnya dan selanjutnya dicari solusi untuk memperbaiki kesalahan tersebut agat tujuan pendidikan dapat tercapai dengan baik.

Dalam pandangan Islam segala sesuatu harus dilakukan secara terencana, dan teratur. Tidak terkecuali dengan proses kegiatan belajar-mengajar yang merupakan hal yang harus diperhatikan, karena substansi dari pembelajaran adalah membantu siswa agar mereka dapat belajar secara baik dan maksimal. Supervisor dalam hal ini berarti mengatur atau mengelola serta mengarahkan guru akan sesuatu hal agar menjadi baik.

Berdasarkan hadits di atas, pengawasan dalam Islam dilakukan untuk meluruskan yang bengkok, mengoreksi yang salah dan membenarkan yang hak.

Selain itu berdasarkan hadits yang diriwayatkan oleh Imam Thabrani bahwasanya Rasulullah SAW. bersabda: "Sesungguhnya Allah mencintai orang yang jika melakukan suatu pekerjaan, dilakukan secara itqan (tepat, terarah, dan tuntas) (HR. Thabrani).

d. Integritas; Kejujuran dan Konsisten (Istiqomah)

Prinsip integritas merupakan kepribadian supervisor yang melaksanakan pengawasan dengan mentalitas yang baik penuh kejujuran, simpatik, tanggung jawab, cermat dan konsisten. Hal ini dianjurkan melalui hadis nabi berikut:

\footnotetext{
${ }^{5}$ Abu Isa Atturmudzi, Aljami'ussahih Sunan Tirmidzi, file download html pdf, juz 1. 1996
} 


$$
\begin{aligned}
& \text { عن سفيان أن رجلا قال يا رسول الله أخبرين أمرا في الإسلام لا أسأل عنه أحدا بعدك قال قل آمنت } \\
& \text { بالله ثم استقم قال يا رسول الله فأي شيء أتقي قال فأشار بيده إلى لسانه. }
\end{aligned}
$$

Dari riwayat Sufyan bahwa seseorang berkata: wahai Rasulullah, ceritakanlah kepadaku tentang suatu hal dalam islam, yang tiada seorangpun mempertanyakan hal itu sesudahmu (menjelaskan), beliau bersabda: katakanlah aku beriman kepada Allah SWT., lalu istiqomahlah, ia berkata : wahai Rasulullah, dari apa aku harus takut, lalu beliau menunjuk dengan tangannya ke lidahnya. (H.R. Ahmad).

Hadis tersebut menunjukan bahwa nabi mengajarkan suatu hal yang sangat penting dalam Islam, yakni beriman kepada Allah, istiqomah dalam melakukan segala hal yang bernilai ibadah, terutama dalam mengemban amanah sebagai pendidik, serta konsisten dalam bertutur kata maupun bersikap. Seorang supervisor dan pendidik yang beriman akan selalu memegang amanahnya dengan baik dan bertanggung jawab melaksanakan tugas-tugasnya secara cermat, tertib dan konsisten disertai kejujuran baik secara lisan maupun sikap.

e. Objektivitas; Profesional sesuai keahlian

Dalam hal ini supervisi harus didasarkan atas hubungan professional, bukan atas hubungan pribadi, harus realistis.

$$
\begin{aligned}
& \text { عن جده سعد بن أبي بردة عن النبي صلى الله عليه وسلم قال على كل مسلم صدقة فقالوا ياببي الله فمن }
\end{aligned}
$$

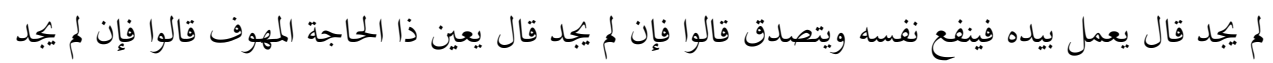

$$
\begin{aligned}
& \text { قال فليعمل بالمعروف وليمسك عن الشر فإها له صدقة. (رواه البخاري) }
\end{aligned}
$$

Dari riwayat kakeknya Sa'id bin Abi Burdah dari Nabi SAW., beliau berkata: Bagi setiap muslim dikenakan shadaqah, mereka berkata: "Wahai nabi Allah (bagaimana) dengan seseorang yang tidak mendapatinya, beliau berkata: hendaknya ia bekerja dengan tangannya kemudian ia manfaatkan untuk dirinya dan bershadaqah, mereka berkata: hendaknya ia menolong orang yang memiliki hajat lagi menderita, mereka berkata: bila tidak dijumpai, beliau berkata: hendaknya ia beramal (berbuat) yang makruf dan menahan diri dari kejahatan, maka sesungguhnya hal itu bernilai shadaqah baginya. (H.R. Bukhori).

Hadits tersebut menunjukkan bahwa seorang supervisor dan pendidik yang professional hendaknya selalu berusaha meningkatkan potensi diri dan memperbaiki segala hal untuk kemajuan bersama di lingkungannya (sekolah dan masyarakat).

5. Pengembangan Supervisi Pendidikan dalam Meningkatkan Profesionalisme Guru

Istilah profesionalisme berasal dari profession, yang berarti pekerjaan. Dalam buku yang ditulis Kunandar yang berjudul Guru Profesional Implementasi Kurikulum Tingkat Satuan Pendidikan disebutkan bahwa profesionalisme berasal 
dari kata "profesi" yang artinya suatu bidang pekerjaan yang ingin atau akan ditekuni oleh seseorang. Profesi juga diartikan sebagai suatu jabatan atau pekerjaan tertentu yang mensyaratkan pengetahuan dan keterampilan khusus yang diperoleh dari pendidikan akademis yang intensif. ${ }^{6}$

Profesionalisme yaitu faham yang mengajarkan bahwa setiap pekerjaan harus dilakukan oleh orang yang professional. Dengan bertitik tolak pada pengertian ini, maka pengertian guru professional adalah orang yang memiliki kemampuan dan keahlian khusus dalam bidang keguruan sehingga ia mampu melakukan tugas dan fungsinya sebagai guru dengan kemampuan maksimal. Dengan kata lain, guru professional adalah orang yang terdidik dan terlatih dengan baik, serta memiliki pengalaman yang kaya di bidangnya. ${ }^{7}$

Mengingat tugas dan tanggung jawab guru yang begitu kompleksnya, maka profesi ini memerlukan persyaratan khusus antara lain:

a. Menuntut adanya keterampilan yang berdasarkan konsep dan teori ilmu pengetahuan yang mendalam

b. Menekankan pada suatu keahlian dalam bidang tertentu sesuai dengan profesinya

c. Menuntut adanya tingkat pendidikan keguruan yang memadai

d. Danya kepekaan terhadap dampak kemasyarakatan dari pekerjaan yang dilaksanakannya

e. Memungkinkan perkembangan sejalan dengan dinamika kehidupan. ${ }^{8}$

Kriteria pendidik atau guru professional, sebagaimana dinyatakan Oemar Hamalik, minimal memiliki persyaratan, yang meliputi: a. bakat sebagai guru, b. keahlian sebagai guru, c. memiliki keahlian yang baik dan terintegrasi, d. mental yang sehat, e. berbadan sehat, f. memiliki pengalaman dan pengetahuan yang jelas, g. guru adalah manusia berjiwa pancasila, h. guru adalah seorang warga Negara yang baik. ${ }^{9}$

Seorang guru adalah hamba Allah SWT. yang mendapat amanah untuk mengajar dan mendidik anak murid yang nantinya akan menjadi penerus bangsa, amanah yang diemban seorang guru merupakan bagian dari amanah yang diemban sebagai khalifah di bumi. Amanah seorang guru adalah bagaimana seorang guru membimbing, membina, mengayomi, dan memberi teladan terhadap peserta didiknya dengan penuh keikhlasan. Oleh karena itu guru harus memiliki "Totalitas Diri" yakni mengorbankan waktu, tenaga, keterampilan, materi, dan pikiran bahkan kehormatan untuk keberhasilan dalam menjalankan tugas mencerdaskan anak bangsa.

Untuk menjadi guru atau pendidik yang professional dan mendapatkan kepuasan dari wali murid serta peserta didiknya, maka guru perlu memperhatikan dan melakukan hal-hal berikut ini:

\section{a. Planning (Perencanaan/Persiapan Diri)}

\footnotetext{
${ }^{6}$ M.Fathurrohman, M.Pd.I dan Dr.Sulistyorini, M.Ag., Meretas Pendidikan Berkualitas dalam Pendidikan Islam, (Yogyakarta: Teras, 2012), hlm. 153

${ }^{7}$ Drs. Moh. Uzer Usman, Menjadi Guru Profesional, (Bandung: PT.Remaja Rosdakarya, 2002), hlm. 15

${ }^{8}$ Drs. Moh.Uzer Usman, Menjadi Guru Profesional, hlm. 15

${ }^{9}$ M.Fathurrohman dan Sulistyirini, Meretas Pendidikan Berkualitas dalam Pendidikan Islam, hlm.166-167
} 
Memlanning atau mempersiapkan diri dengan baik sebelum mengajar adalah wujud seorang guru yang menghargai diri sendiri dan menghargai peserta didik. Seorang guru yang professional persiapannya benar-benar matang, di antaranya; mempersiapkan perangkat pembelajaran yang mengacu pada silabus atau kurikulum yang berlaku, menguasai materi pelajaran, memilih dan menggunakan metode yang tepat sesuai dengan materi, situasi dan kondisi peserta didik, memperhitungkan dan menggunakan waktu seefisien mungkin, memilih dan memanfaatkan media pembelajaran yang tepat.

b. Meningkatkan Wibawa dan Kredibilitas

Guru professional selalu berusaha meningkatkan kinerjanya dengan menambah wawasan keilmuannya dan pengalamannya, menguasai teknologi masa kini, memanfaatkan dan mengembangkan keterampilan yang dimilikinya, menjadi pendidik yang bijaksana, mampu mengendalikan emosi atau amarahnya, optimis dalam setiap langkah dan kehidupannya mencapai kesuksesan,, menunjukkan kesederhanaan dan sebagainya.

c. Menarik simpati peserta didik

Seorang pendidik yang professional akan selalu berpenampilan menawan di setiap saat, mudah menyapa dan memberikan senyuman pada peserta didiknya, menjalin rasa saling memiliki dan saling pengertian, selalu meminta maaf jika berbuat khilaf atau salah, memberikan reward dan selalu memotivasi peserta didik dalam semangat belajar.

d. Memahami peserta didik

Guru yang baik yaitu guru yang bisa menjadi pendengar setia bagi peserta didiknya, berempati terhadap mereka, memahami gaya belajar mereka, menghargai pendapat para peserta didik.

e. Meningkatkan disiplin

Guru merupakan role model bagi peserta didiknya. Gurulah yang menjadi panutan, teladan baik tutur kata maupun sikap tingkah lakunya. Salah satu keteladanan yaitu disiplin, baik disiplin waktu; masuk dan keluar kelas, disiplin menegakkan aturan, sikap maupun disiplin dalam beribadah.

f. Evaluasi diri dan peserta didik

Guru yang professional enggan meminta saran dan kritikan dari para peserta didik maupun pendidik yang lain, terutama dari supervisor atau kepala sekolah agar secepatnya memperbaiki dan meningkatkan kinerjanya. Selain mengevaluasi diri juga guru harus memberi penilaian atau evaluasi terhadap peserta didik; yakni penilaian harian dengan memberi tugas sekolah atau PR, memberikan tugas yang menantang dan mengasyikkan serta tidak kalah penting yaitu evaluasi ruhiyah mereka; mengajak bermuhasabah atau merenungi kesalahan dan dosa-dosa dan memotivasi agar selalu semangat beribadah dengan mengharap ridha Allah SWT.

g. Hubungan kerjasama dengan Orang tua Peserta Didik dan masyarakat sekitar. Guru professional tidak hanya menguasai lingkungan kelas dan sekolah, tetapi lebih luas lagi yakni dengan selalu berusaha menjalin hubungan silaturrahim dengan orang tua peserta didik dan tokoh masyarakat, baik melalui pemberian penyuluhan kepada mereka maupun mengadakan pelatihan-pelatihan karya yang bisa membantu mengembangkan perekonomian masyarakat. 


\section{Kesimpulan}

Supervisi pendidikan merupakan proses meneliti, mengoreksi dan menilai kinerja guru atau pendidik, mengarahkan dan memberikan solusi atas berbagai kekurangan dari para pendidik serta memperbaiki dan mengembangkan segala hal dalam kemajuan pendidikan.

Supervisi pendidikan dalam perspektif hadis nabi berkaitan dengan prinsip supervise tersebut, yakni hadis tentang "Akuntabilitas, Edukatif, Korektif, Integrirtas, Kredibilitas, serta Objektivitas.”

Peningkatan profesionalisme guru dapat dilakukan dengan memperhatikan dan melaksanakan ; planning, berpenampilan wibawa, memahami karakteristik peserta didik, pemberian evaluasi terhadap peserta didik dan menjalin kerjasama dengan orang tua peserta didik serta masyarakat.

\section{Daftar Pustaka}

Daryanto, Administrasi Pendidikan, Jakarta: Rineka Cipta, 2014.

Engkoswara dan Komariah Aan, Administrasi Pendidikan, Bandung: Alfabeta, 2015.

Fathurrohman, dan Sulistyorini, Meretas Pendidikan Berkualitas Pendidikan Islam, Yogyakarta: Teras, 2012.

Haryono, 101 Jurus Jitu Menjadi Guru Hebat, Yogyakarta: Arruzz $\quad$ Media, 2017.

Majid, Khon, Abdul, Hadits Tarbawi, Jakarta: PT . Kencana Persada Media Group, 2012.

Nasih Ulwan, Abdullah, Pendidikan Anak Dalam Islam, terj., Jakarta: Pustaka Amani, 2007.

Oteng Sutisna, Administrasi dan Supervisi Pendidikan Dasar dan Teoritis Untuk Praktek Profesional, Bandung: Angkasa 1989.

Purwanto M. Ngalim, Administrasi dan Supervisi Pendidikan, Bandung: PT. Remaja Rosdakarya, 2014.

Ulama'I Hasan Asy'ari, Hadis-Hadis Pendidikan Mental Islami, Semarang: IAIN Walisongo, 2008

Usman Moh. Uzer, Menjadi Guru Profesional, Bandung: PT. Remaja Rosdakarya, 2002 